J. Lake Sci.(湖泊科学), 2019, 31(4): 941-949

DOI 10. 18307/2019. 0423

(c) 2019 by Journal of Lake Sciences

\title{
太湖藻型湖区沉积物中生物易降解物质组成及分布规律"
}

\author{
祁 闯 ${ }^{1}$, 方家琪 ${ }^{1}$,张利民 ${ }^{1,2}$, 雷 波 $^{1}$, 汤响成 ${ }^{1}$, 王国祥 ${ }^{1,2 * *}$ \\ (1: 南京师范大学环境学院,南京 210097) \\ ( 2 : 江苏省地理信息资源开发与利用协同创新中心, 江苏省环境演变与生态建设重点实验室, 江苏省水土环境生态修复 \\ 工程实验室,南京 210023)
}

\begin{abstract}
摘 要: 为研究富营养化湖泊藻型湖区沉积物中生物易降解有机质的组成及其垂向分布特征, 选取太湖竺山湾湖滨带和 开敞湖区采集沉积物柱状样, 利用微电极技术测定沉积物一水界面理化指标的剖面特征, 并对沉积物中含水率、烧失量、 色素含量、总有机碳、总氮以及生物易降解物质 (总蛋白、总糖和总脂) 进行测定. 结果表明: 藻型湖区沉积物一水界面处 溶解氧、 $\mathrm{pH}$ 和氧化还原电位在垂向剖面上呈现出随深度增加而下降的趋势, 空间上存在明显的异质性, 湖滨带沉积物一 水界面溶解氧、 $\mathrm{pH}$ 和氧化还原电位显著低于开敞湖区, 而沉积物一水界面 $\mathrm{H}_{2} \mathrm{~S}$ 浓度在垂向上则表现为随深度先降低而后 升高的趋势. 此外, 藻型湖区沉积物中生物易降解有机质的组成和分布同样存在明显的空间异质性. 组成上以脂类 $(7.7$ $\mathrm{mg} / \mathrm{g})$ 为主, 其次是糖类 $(4.5 \mathrm{mg} / \mathrm{g})$, 蛋白质 $(0.8 \mathrm{mg} / \mathrm{g})$ 含量最低;空间上, 湖滨带沉积物中生物易降解有机质含量显著高 于开敞湖区,表层 $15 \mathrm{~cm}$ 以上沉积物含水率和烧失量较高, 有机质含量丰富.
\end{abstract}

关键词: 太湖;藻积层;生物易降解物质;微电极;营养盐;沉积物

\section{Composition and distribution of biodegradable compounds in phytoplankton-dominated zone of Lake Taihu}

QI Chuang ${ }^{1}$, FANG Jiaqi ${ }^{1}$, ZHANG Limin ${ }^{1,2}$, LEI Bo ${ }^{1}$, TANG Xiangcheng ${ }^{1} \&$ WANG Guoxiang $^{1,2 * *}$

(1: School of Environment, Nanjing Normal University, Nanjing 210097, P.R.China)

(2: Jiangsu Center for Collaborative Innovation in Geographical Information Resource Development and Application Jiangsu Key Laboratory of Environmental Change and Ecological Construction, Institute of Water Environmental Eco-remediation, Nanjing 210023, P.R.China)

Abstract: To better understand the distribution and composition of sedimentary bioclastic material in phytoplankton-dominated eutrophic lakes, we combined a spatial survey of surface sediments with sediment core analyses to quantify moisture content, ignition loss, pigments, total organic nitrogen, total nitrogen and biodegradable compounds changes in the littoral zones and off-shore areas. Results show that dissolved oxygen, $\mathrm{pH}$ and oxidation-reduction potential presented a clear downward trend with increasing depth, while the $\mathrm{H}_{2} \mathrm{~S}$ concentrations gradually decreased with increasing depth and then increased in deeper layers until they reached a maximum and remained stable. In the littoral zones, the physicochemical parameters were mostly higher than that in the offshore areas. In addition, the biodegradable compounds showed significant spatial variability. Results show that lipids $(7.7 \mathrm{mg} / \mathrm{g})$, followed by carbohydrates $(4.5 \mathrm{mg} / \mathrm{g})$, was the dominant component of sedimentary bioclastic material. Data shows that the distribution of high moisture content, ignition loss and biodegradable compounds were mainly localization in the surface $15 \mathrm{~cm}$ of sediments.

Keywords: Lake Taihu; cyanobacterial-derived bioclastic deposit; biogradable compounds; microsensor; nutrient; sediment

湖泊是有机质生产、迁移、储存的重要场所. 它不仅具有较高的生物生产力,还汇集了丰富的陆源物质,

* 国家水体污染控制与治理科技重大专项 (2017ZX07203-003，2017ZX07202-004)、国家自然科学基金项目 (41703105，41573061) 和江苏省研究生科研创新计划 (KYCX17_1065) 联合资助. 2018-12-18 收稿; 2019-01-28 收修改稿. 祁闯 (1991 ), 男, 博士研究生; E-mail: qeenjnu@163.com.

** 通信作者; E-mail: wangguoxiang@ njnu.edu.cn. 
而且湖泊较强的生物百功能, 带来了较快的生物源沉积 ${ }^{[1-2]}$. 因此, 湖泊真实地记录了流域人类活动和湖泊 自然环境演变的信息,同时也是揭示气候变化和区域响应的重要信息载体 ${ }^{[3-4]}$.

在富营养化和气候变化的双重影响下, 湖泊藻类水华暴发强度大、持续时间长、暴发频率高, 大量的蓝 藻聚集、堆积、衰亡后沉积于沉积物表层,逐渐发育形成有机质含量较高的“藻积层”. 研究表明,在富营养化 湖泊巢湖、太湖、滇池, 甚至部分水库, 表层沉积物均以藻源性有机质为主 ${ }^{[5-7]}$. 此外, 在藻类衰亡沉降过程 中, 沉积物的组成及活性不断发生变化, 其中部分活性高的有机质优先降解, 如色素、蛋白质、糖类等, 而腐 殖质等较难降解有机质会保留在沉积物中 ${ }^{[6]}$. 对 40 种不同藻类细胞组分研究表明, 藻细胞主要由蛋白质、 糖类和脂类物质组成, 不同组分的相对含量因藻的种类不同而有所差异 ${ }^{[8-9]}$. 通常蓝藻中蛋白质含量较高 ( $41 \% \sim 69 \%$ ), 而硅藻中脂类含量较高 ( $5 \% \sim 43 \%$ ), 其中蛋白质是有机质中活性较高的组分, 其含量和组成 的变化对于底栖生物的分布、群落结构及动态有重要的影响 ${ }^{[10-12]}$. 与此同时, 藻类残体仍含有碳、氮、磷、硫 等多种元素, 沉降后使得表层沉积物有机质厌氧代谢增强, 呈现厌氧强还原环境, 在厌氧微生物作用下, 有 机硫分解和硫酸盐还原产生大量 $\mathrm{H}_{2} \mathrm{~S}$ 以及硫醇、硫梄类化合物致臭 ${ }^{[13-14]}$; 此外, 沉积物中的铁氧化物被戻氧 微生物利用转化为还原态, $\mathrm{H}_{2} \mathrm{~S}$ 与 $\mathrm{Fe}^{2+}$ 等形成金属硫化物, 金属硫化物被悬浮颗粒吸附再悬浮至水体中致 黑 ${ }^{[15-16]}$, 造成水体黑臭, 并向水体中释放大量碳、氮、磷等物质, 导致内源释放, 加速湖泊富营养化进程 ${ }^{[17-21]}$. 因此, 藻积层中有机质的组成和降解状态, 不仅影响着底栖生物和微生物的组成及活性, 同时也影响着湖泊 水体和沉积物中碳、氮、磷、硫等多种元素的生物地球化学循环.

目前关于沉积物中易降解有机质的研究多集中在海洋和河流生态系统中, 而湖泊沉积物的研究主要集 中在有机质含量与来源、粒径分布、重金属含量、营养盐含量及其释放特征等方面 ${ }^{[2,22-23]}$. 但是, 随着富营养 化程度不断加剧, 湖泊沉积物中大量的藻源性有机质在降解和转化过程中又将对湖泊环境产生了哪些影 响? 沉积物中生物易降解物质组成如何? 其在垂直方向上有何分布特征? 研究探讨上述问题, 对于调控富 营养化湖泊内源污染、改善水质、防止富营养化湖泊衰亡具有重要的理论和实际意义.

\section{1 材料与方法}

\section{1 研究区概况及样品采集}

太湖竺山湾是典型的藻型湖区, 该区域的藻类水华呈现出持续时间长、暴发频率加快的趋势 ${ }^{[24]}$. 而湖 滨带多存在堤下深漕 (修建大堤时取土而成), 部分岸段湖滨带还有离岸分布的芦苇群丛, 在主导风向东南 风的影响下, 大量藻类碎屑残体堆积, 受芦苇群丛的阻隔, 藻类碎屑残体及水草残体从开场湖区随风生流进 人芦苇群从内, 难以回到湖区, 使得藻类碎屑残体堆积造成了淤泥黑臭. 根据 2016 年 4-10 月蓝藻预警期 间太湖蓝藻暴发频率分布 ${ }^{[25]}$, 于 2018 年 8 月, 分别在竺山湾挺水植物湖滨带和开敞湖区利用柱状沉积物采 样器 (Corer 60 , 奥地利), 采集沉积物样品, 从湖滨带到开敞区共设置 4 个点位 (图 1), C1 和 C2 位于开敞湖 区, 离岸距离 3 5 km, 周围无水生植物分布, L1 和 L2 位于符渎港附近的湖滨带, 湖滨带补植有整齐的芦苇 群丛和自然分布的芦苇群丛, 离岸距离 $0.5 \mathrm{~km}$. 每个点位采集 3 根柱状样, 现场严格按 $2 \mathrm{~cm}$ 切割分层, 并将 相同层沉积物样品收集到同一自封袋中混匀,当天运回实验室冷藏保存.

\section{2 样品分析与数据处理}

每个采样点还分别采集沉积物柱状样, 当天运回实验室. 在 $20^{\circ} \mathrm{C}$ 室温下, 使用丹麦的微电极系统 (Unisense A/S, Arbus, 丹麦) 对沉积物一水界面 $\mathrm{O}_{2} 、 \mathrm{H}_{2} \mathrm{~S}$ 、氧化还原电位 ( Eh) 、 $\mathrm{pH}$ 进行测定, 垂向测量间隔为 $500 \mu \mathrm{m}$. 总氮 $(\mathrm{TN})$ 浓度采用碱性过硫酸钾消解法测定; 总有机碳 (TOC) 浓度采用总有机碳分析仪测定 (Multi N/C 3100, 德国 Jena 公司), 准确称取 $0.05 \mathrm{~g}$ 冷冻干燥后的沉积物样品至燃烧舟中, 用 $0.5 \mathrm{~mol} / \mathrm{L}$ 的 $\mathrm{HCl}$ 浸润样品酸化, 并置于烘箱中 $60^{\circ} \mathrm{C}$ 干燥 $8 \mathrm{~h}$ 以上, 上机测试. 叶绿素 $\mathrm{a}$ 和脱镁叶绿素含量使用丙酮提取, 紫外分光光度法测定 ${ }^{[26]}$. 含水率和烧失量分别按 GB 7172-1987 和 GB 7876-1987 测定 ${ }^{[27]}$. 蛋白质 (PRT) 含量用改进的 Lowry 法 ${ }^{[28]}$ 测定, 称取 $0.25 \mathrm{~g}$ 冷冻干燥后的沉积物样品于 $10 \mathrm{ml}$ 离心管中, 加人 $6 \mathrm{ml}$ 的 0.1 $\mathrm{mol} / \mathrm{L}$ 的 $\mathrm{NaOH}$ 溶液, 置于摇床在 $60^{\circ} \mathrm{C}$ 下提取 $2 \mathrm{~h}$ 后, 冷却至室温后在 3000 转 $/ \mathrm{min}$ 离心 $10 \mathrm{~min}$, 在 $10 \mathrm{ml}$ 离 心管中先加人 $1 \mathrm{ml}$ 蛋白质提取物, 再加人 $5 \mathrm{ml}$ 碱性铜溶液, 混匀静置 $10 \mathrm{~min}$ 后加人 $0.5 \mathrm{ml}$ 的 $1 \mathrm{~mol} / \mathrm{L}$ 福林 酚试剂立即摇匀, 静置 $30 \mathrm{~min}$ 使反应完全, 于 $750 \mathrm{~nm}$ 测定吸光度; 总糖 ( CHO ) 用苯酚一硫酸法测定 ${ }^{[29]}$, 称取 


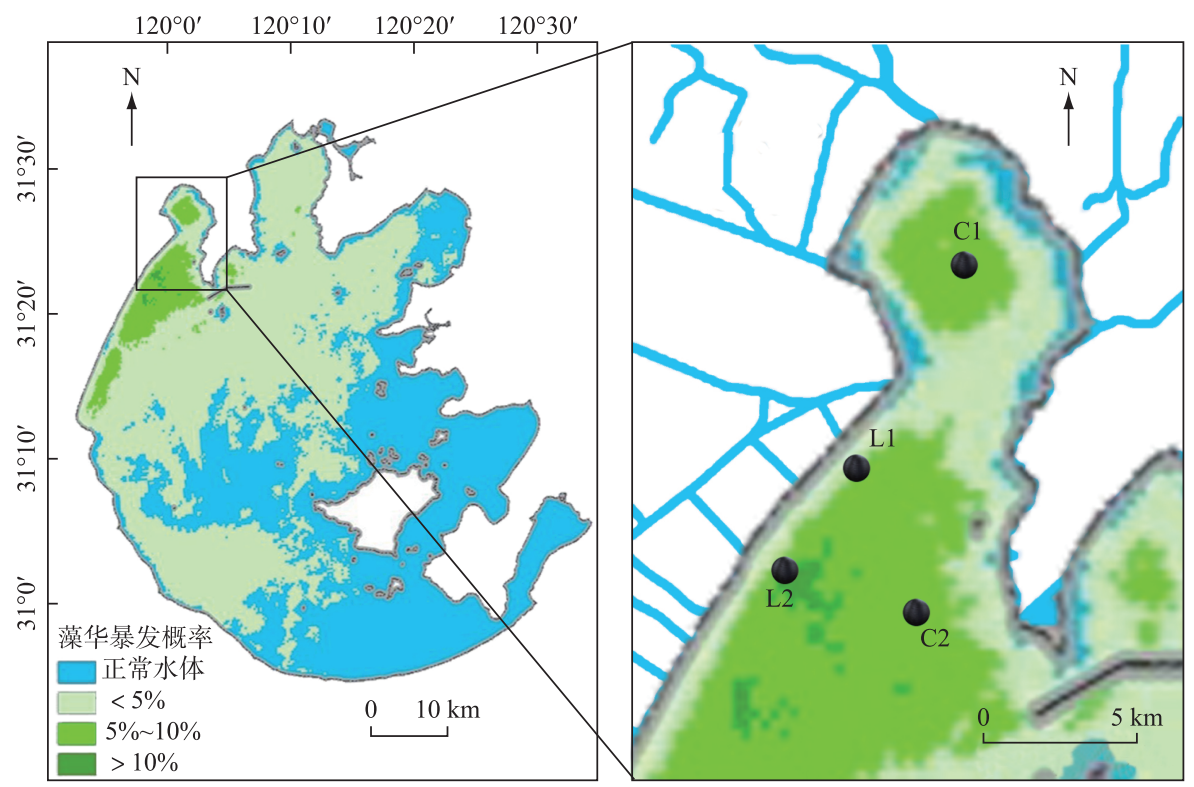

图 1 太湖竺山湾采样点分布

Fig.1 Distribution of sampling sites in Zhushan Bay of Lake Taihu

$0.5 \mathrm{~g}$ 冷冻干燥后的沉积物样品于 $50 \mathrm{ml}$ 离心管中, 加人 $20 \mathrm{ml}$ 高纯水, 超声混合均匀, 取 $2 \mathrm{ml}$ 上述混合样品, 加人 $2 \mathrm{ml}$ 苯酚溶液和 $10 \mathrm{ml}$ 浓硫酸, 立即混合均匀, 4000 5000 转/ $\min$ 离心 $30 \mathrm{~min}$, 于 $485 \mathrm{~nm}$ 测定吸光度; 总脂 (LIP) 用甲醇一氯仿法测定 ${ }^{[29]}$, 称取 $0.25 \mathrm{~g}$ 冷冻干燥后的沉积物样品至 $50 \mathrm{ml}$ 离心管中, 加人 $20 \mathrm{ml}$ 混 合液 ( $\mathrm{pH}=7.4$ 磷酸盐缓冲液: 氯仿: 甲醇 $=0.8: 1: 2)$ 后用浴旋振荡器混匀, 置于暗处静置 $2 \mathrm{~h}$ 后, 以 5000 转 $/ \mathrm{min}$ 离心 $10 \mathrm{~min}$, 将上清液转移至试管中, 向上清液中加人 $5.26 \mathrm{ml}$ 氯仿、 $5.26 \mathrm{ml}$ 磷酸盐缓冲液, 静置过夜 使其分层, 用移液器吸取 $2 \mathrm{ml}$ 下层萃取液至 $25 \mathrm{ml}$ 比色管中, 用氮气在 $50^{\circ} \mathrm{C}$ 下吹干. 氮气吹干后加 $4 \mathrm{ml}$ 浓硫 酸, 在电热板中 $200^{\circ} \mathrm{C}$ 加热 $15 \mathrm{~min}$, 然后加人 $6 \mathrm{ml}$ 蒸馏水, 摇匀, 冰浴 $10 \mathrm{~min}$ 后, 于 $375 \mathrm{~nm}$ 测定吸光度值. 每 个样品设置 3 个重复, 用于计算平均值及标准偏差.

利用 Excel 和 Origin 9.0 软件对实验各类数据进行整理作图; 采用 SPSS 19.0 软件进行单因素方差分析 (One-way ANOVA).

\section{2 结果与讨论}

\section{1 沉积物理化特性的垂向变化特征}

藻型湖区沉积物一水界面处 DO 、 $\mathrm{pH}$ 和 Eh 在垂向剖面上呈现出随深度增加而下降的趋势, 空间上存在 明显的异质性, 湖滨带 ( L1 和 L2) 沉积物一水界面 DO $\mathrm{pH}$ 和 Eh 显著低于开敞湖区 ( C1 和 C2, P < 0.01). 水 体中 DO 的垂向分布比较稳定, 湖滨带和开敞湖区水体 DO 的均值分别为 $115.7 \pm 3.5$ 和 $150.8 \pm 3.4 \mu \mathrm{mol} / \mathrm{L}$, DO 的渗透深度分别为 $2.3 \pm 0.4$ 和 $3.3 \pm 0.4 \mathrm{~mm}$, 在深度 $3.5 \mathrm{~mm}$ 以下 DO 浓度降低至零, 且保持稳定的状态 (图 2a). 不同监测点位沉积物 $\mathrm{pH}$ 值也存在明显差异, 整体呈现随深度增加而下降的趋势, 开敞湖区沉积物 整体以碱性条件为主, 而湖滨带的沉积物随着深度的增加, 由碱性逐渐向酸性条件转变 (图 2b). 沉积物一水 界面 Eh 的垂向分布规律与 DO 类似, 开敞湖区沉积物 Eh 大于 $350 \mathrm{mV}$ (图 2c), 而湖滨带有大量藻源性有机 碎屑作为还原性物质加入后, 使得 Eh 不断降低, 这与 Ding 等 ${ }^{[30]}$ 研究结果较为一致. 由于藻类的暴发、聚积 和腐解过程, 往往是在水柱和沉积物表层发生的, 当大量的藻类残体沉降到沉积物表层后, 将会发生沉积 物一水界面生物地球化学过程. 首先藻类的大量聚积沉降会影响沉积物一水界面的氧化还原环境, 沉积物本 身就存在化学好氧和微生物好氧作用, 当藻类碎屑残体沉降到沉积物表层后, 沉积物一水界面氧的消耗作用 
加快 ${ }^{[14,31]}$. 因此, 当藻类碎屑残体消耗溶氧后, 随着深度增加沉积物中 DO 和 $\mathrm{Eh}$ 就呈现下降趋势, 形成厌氧 强还原的状态.
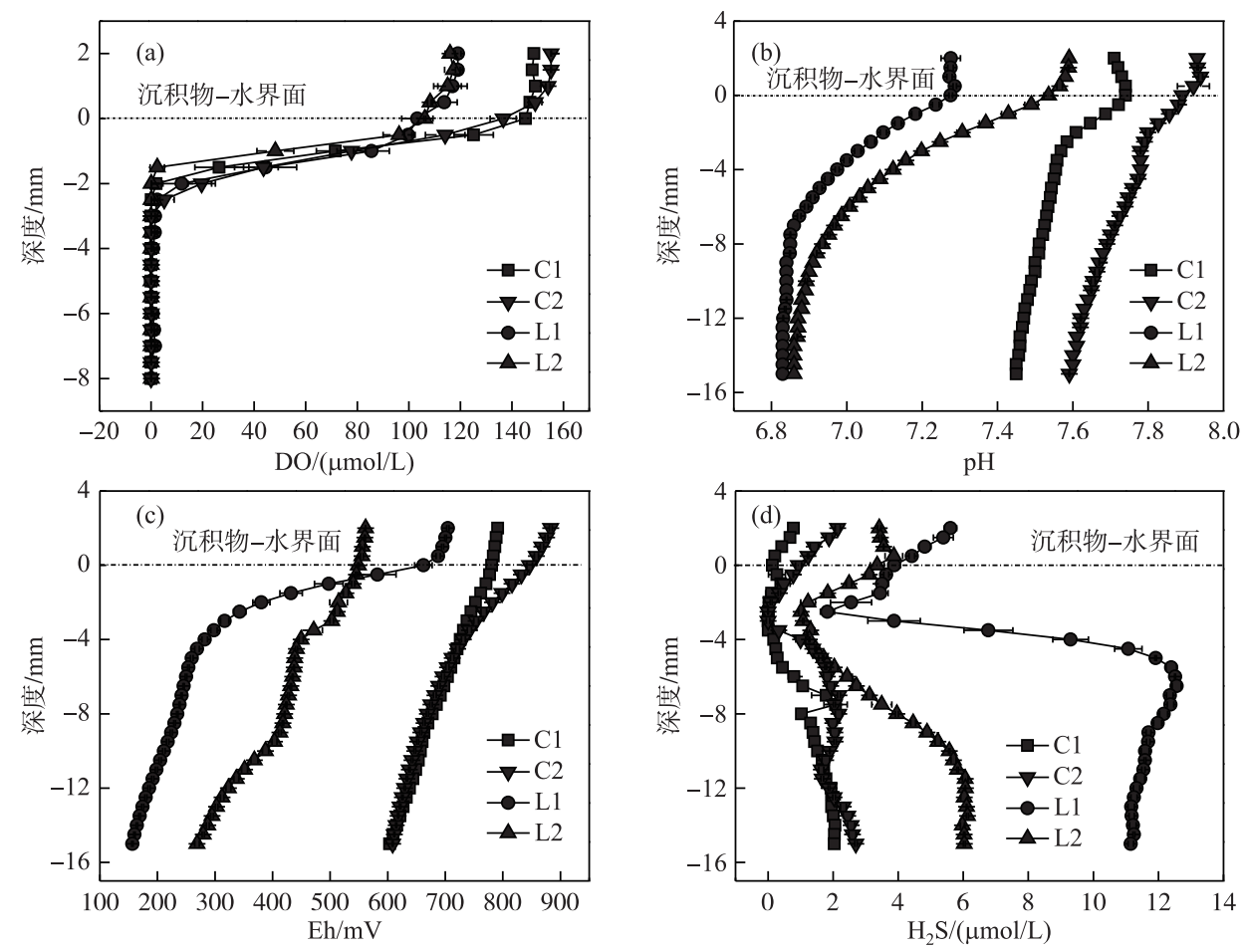

图 2 沉积物一水界面 DO 、 pH、Eh 和 $\mathrm{H}_{2} \mathrm{~S}$ 浓度的剖面分布

Fig. 2 The profile distribution of DO, pH, Eh and $\mathrm{H}_{2} \mathrm{~S}$ concentration of sediment-water interface

沉积物一水界面 $\mathrm{H}_{2} \mathrm{~S}$ 的垂向上则表现为随深度先降低而后升高的趋势 (图 $2 \mathrm{~d}$ ). 在 $3.5 \mathrm{~mm}$ 深度附近 $\mathrm{H}_{2} \mathrm{~S}$ 浓度降到最低, 之后随深度增加而逐渐升高, 湖滨带沉积物中 $\mathrm{H}_{2} \mathrm{~S}$ 浓度明显高于开敞湖区, 湖滨带 ( L1) 沉积物中 $\mathrm{H}_{2} \mathrm{~S}$ 浓度峰值为 $12.6 \mu \mathrm{mol} / \mathrm{L}$, 而开敞湖区 $(\mathrm{C} 2) \mathrm{H}_{2} \mathrm{~S}$ 浓度峰值仅为 $2.5 \mu \mathrm{mol} / \mathrm{L}$. 究其原因, 由于硫 酸盐的还原是水生物环境中 $\mathrm{H}_{2} \mathrm{~S}$ 产生的重要途径, 硫酸盐还原菌利用硫酸根作为电子受体进行无氧呼吸作 用产生 $\mathrm{H}_{2} \mathrm{~S}^{[32]}$, 研究表明, 蓝藻衰亡腐解过程促进了硫在沉积物中的累积 ${ }^{[33]}$, 此外 $\mathrm{H}_{2} \mathrm{~S}$ 是蛋白质在厌氧介 质中分解的产物, 而藻细胞中含有硫氨基酸, 在微生物作用下转化为一系列硫化合物 ${ }^{[34]}$, 因而在厌氧沉积物 中, 藻类腐解的产物在 $\mathrm{H}_{2} \mathrm{~S}$ 产生中起着重要的作用.

随着深度的增加, 沉积物含水率和烧失量同样呈现出下降的趋势, 湖滨带 (L1 和 L2)沉积物含水率和烧 失量均高于开敞湖区 ( C1 和 C2), 开敞湖区表层 $15 \mathrm{~cm}$ 以上沉积物含水率和烧失量较高, 而后逐渐趋于稳定 (图 3). 究其原因, 由于湖滨带沉积物主要以蓝藻碎屑和水草残体淤积为主, 而开敞湖区主要以悬浮泥沙为 主 $^{[20]}$, 故导致湖滨带沉积物烧失量远高于开敞湖区.

\section{2 沉积物中色素含量及有机质来源辨析}

色素作为沉积物中反演湖库生态环境的重要化学生物标志物, 不仅可以反映藻类生物量和表征特定生 物来源, 还可以记录藻类群落演替和初级生产力变化等重要信息 ${ }^{[26,35]}$. 脱镁叶绿素是叶绿素 $\mathrm{a}$ 的降解产物, 可以用叶绿素 $\mathrm{a}$ 和脱镁叶绿素来表征从水体中输人的有机质质量 ${ }^{[26]}$. 由图 4 可知, 沉积物中叶绿素 $\mathrm{a}$ 和脱 镁叶绿素含量的垂向分布特征与含水率和烧失量具有一致性, 开敞湖区 ( C1 和 C2) 表层 $15 \mathrm{~cm}$ 沉积物呈现 明显的下降趋势, 随后趋于稳定. 开敞湖区沉积物中叶绿素 $\mathrm{a}$ 和脱美叶绿素含量的最大值分别为 $3.7 \pm 0.2$ 和 $26.6 \pm 0.7 \mu \mathrm{g} / \mathrm{g}$, 而湖滨带沉积物叶绿素 $\mathrm{a}$ 和脱镁叶绿素含量的最大值分别为 $14.9 \pm 0.6$ 和 $32.5 \pm 0.3 \mu \mathrm{g} / \mathrm{g}$, 这 

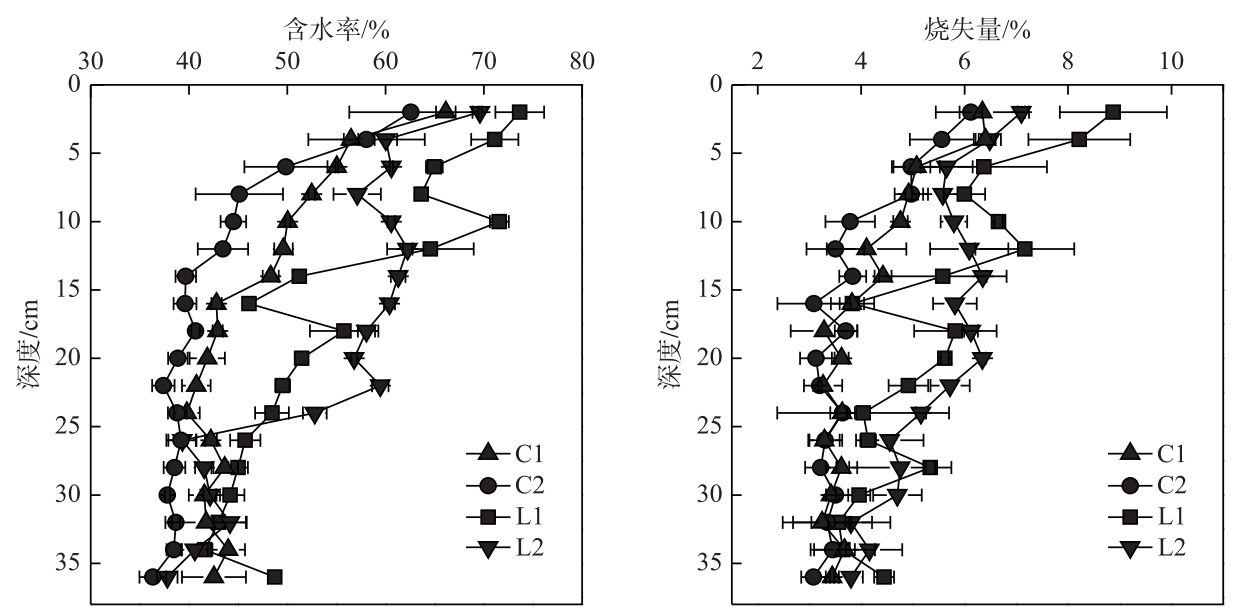

图 3 沉积物中含水率和烧失量的垂向变化

Fig.3 Vertical changes of inmoisture content and ignition loss in the sediment profiles

与何延召等 ${ }^{[6]}$ 对巢湖沉积物中叶绿素 $\mathrm{a}$ 及其降解产物脱镁叶绿素的研究结果一致, 巢湖表层沉积物中叶绿 素含量在 1.3 27.4 $\mu \mathrm{g} / \mathrm{g}$ 之间, 脱镁叶绿素含量在 $1.0 \sim 32.1 \mu \mathrm{g} / \mathrm{g}$ 之间, 沉积物有机质主要以藻源性有机碎 屑组成为主. 研究表明, 近年来, 随着气候变化和富营养化程度的加剧, 在富营养化湖泊巢湖、太湖、滇池, 甚 至部分水库, 表层沉积物均以藻源性有机质为主 ${ }^{[5-7]}$.
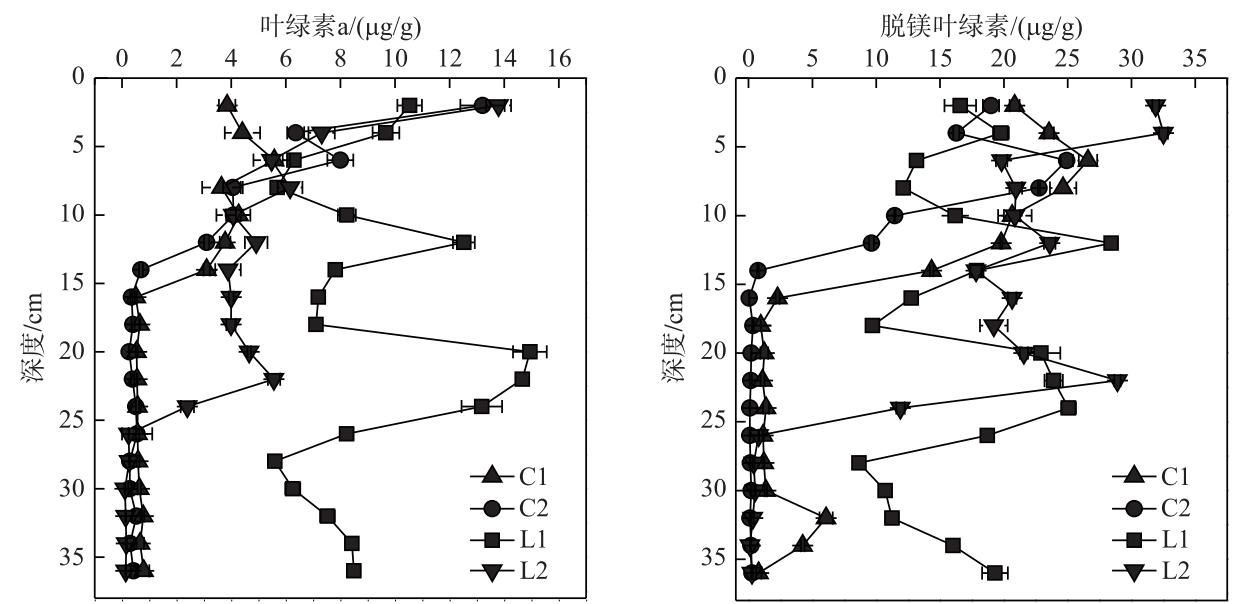

图 4 沉积物中叶绿素 a 和脱镁叶绿素含量的垂向变化

Fig.4 Vertical changes of Chl.a and phaeophytin contents in the sediment profiles

为进一步验证沉积物中有机质来源, 对沉积物中 TOC 和 TN 含量进行分析. 由于陆生高等植物纤维素 含量较高而蛋白质含量较低, 而湖泊内源有机质富含蛋白质, 纤维素含量低. 一般而言, 陆生高等植物的有 机质 $\mathrm{C} / \mathrm{N}$ 比通常为 $20 \sim 30$, 内源藻类有机质 TOC/TN 比为 $4 \sim 10$ 之间, 沉积物有机质 TOC/TN 比大于 10 则 认为受到藻源性和陆源性有机质的共同影响 ${ }^{[23,36]}$. 因此, 利用沉积物中碳氮元素比可以判断沉积物中有机 质的来源是湖泊自身还是外源输人. 由图 5 可知, 湖滨带 (L1 和 L2) 沉积物中, TOC/TN 分别在 $5.6 \sim 7.3$ 和 $8.3 \sim 11.3$ 之间, 而开敞湖区 ( C1 和 C2 ) 沉积物中, TOC/TN 比分别在 6.3 13.1 和 $7.2 \sim 19.8$ 之间. 究其原因, 在主导风向东南风的作用下, 在竺山湾湖滨带、侵蚀漕及挺水植物群丛内, 堆积了大量碎屑残体而形成堆积 层, 该堆积层主要是藻类碎屑残体占优, 局部区域夹带着水生植物碎屑残体及外源有机质, 因而 TOC/TN 偏 
低 ${ }^{[24]}$. 因此, 根据以上的结果综合判断, 太湖西北湖区竺山湾沉积物中有机质以澡源性为主, 而开敞湖区沉 积物中有机质则呈现出藻源性和陆源性混合输人的特征.

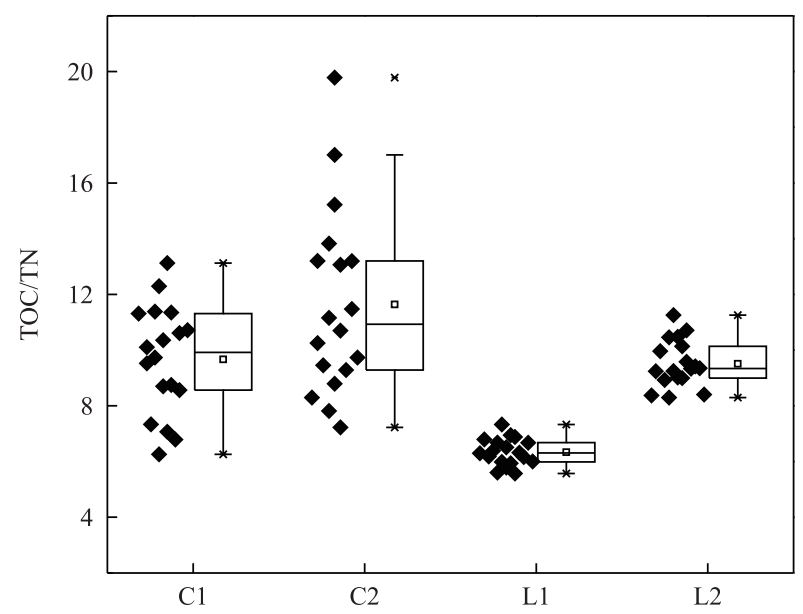

图 5 沉积物中碳氮比的空间变化

Fig. 5 The spatial changes of TOC/TN ratios in the sediment profiles

\section{3 沉积物中生物易降解有机质的垂向分布特征}

藻型湖区沉积物中生物易降解有机质的组成和分布存在明显的空间异质性. 沉积物中生物易降解成分 占 TOC 的比重在 $46.3 \% \sim 77.9 \%$ 之间, 组成上以脂类 ( $7.7 \mathrm{mg} / \mathrm{g}$ ) 含量为主, 其次是糖类 $(4.5 \mathrm{mg} / \mathrm{g}$ ), 蛋白质 $(0.8 \mathrm{mg} / \mathrm{g})$ 含量最低; 空间上, 湖滨带沉积物中生物易降解有机质含量显著高于开敞湖区 $(P<0.05)$, 湖滨带 沉积物中总蛋白、总糖和总脂的含量分别在 $0.1 \sim 3.5 、 3.1 \sim 16.3$ 和 $6.3 \sim 10.9 \mathrm{mg} / \mathrm{g}$ 之间, 而开敞湖区中分别在 $0.1 \sim 1.9 、 2.5 \sim 6.0$ 和 4.3 9.6 mg/g 之间 (图 6). 这与富营养化湖泊巢湖沉积物中易降解有机质的组成较为 一致, 巢湖沉积物中总蛋白、总糖和总脂含量分别在 $0.6 \sim 5.5 、 1.6 \sim 6.5$ 和 $1.0 \sim 3.9 \mathrm{mg} / \mathrm{g}$ 之间 ${ }^{[6]}$. 究其原因, 一方面, 湖滨带更偏向滞水环境, 有利于藻类碎屑残体的堆积, 而开敞湖区水动力更强, 沉积物再悬浮更严 重, 有机质降解更加充分, 故表现为生物易降解有机质在湖滨带富集的特征. 另一方面, 在富营养化状态下, 藻类碎屑残体的大量沉积, 其中部分活性高的有机质优先降解, 如色素、蛋白质、糖类等, 而腐殖质等较难降 解有机质会保留在沉积物中. 对 40 种不同藻类细胞组分研究表明, 藻细胞主要由蛋白质、糖类和脂类物质 组成, 不同组分的相对含量因藻的种类不同而有所差异 ${ }^{[8-9]}$. 通常蓝藻中蛋白质含量较高 $(41 \% \sim 69 \%)$, 而硅 藻中脂类含量较高 ( $5 \% \sim 43 \%$ ), 其中蛋白质是有机质中活性较高的组分, 其含量和组成的变化对于底栖生 物的分布、群落结构及动态有重要的影响 ${ }^{[11-12]}$. 虽然藻类衰亡后释放多种有机质, 且蛋白质和多糖是其主要 组成, 但其降解较快 ${ }^{[37]}, 4$ 天内可分解其自身干重的 $50 \%{ }^{[38]}$, 大量藻类碎屑残体在沉降到湖底之前, 蛋白质 等最易降解的有机质基本降解完全, 其易降解程度表现为: 蛋白质 $>$ 总糖 $>$ 总脂 ${ }^{[12]}$, 因而沉积物中蛋白质含 量较低, 而脂类含量较高.

\section{3 结论}

对富营养化湖泊藻型湖区沉积物一水界面理化指标的剖面特征及沉积物中生物易降解有机质的组成和 分布特征进行研究, 主要结论如下:

1) 藻类碎屑残体沉降会影响沉积物一水界面的氧化还原环境, 因呼吸、微生物降解而造成 DO 浓度降 低,水和沉积物 Eh 快速下降, 形成厌氧强还原环境, 并产生大量 $\mathrm{H}_{2} \mathrm{~S}$.

2) 湖滨带藻类碎屑残体堆积严重, 使得大量光合色素在沉积物中累积, 表层 $15 \mathrm{~cm}$ 以上沉积物含水率 和烧失量较高, 有机质含量丰富.

3) 太湖竺山湾湖滨带沉积物中有机质以藻源性为主, 而开敞湖区沉积物中有机质则呈现出藻源性和陆 

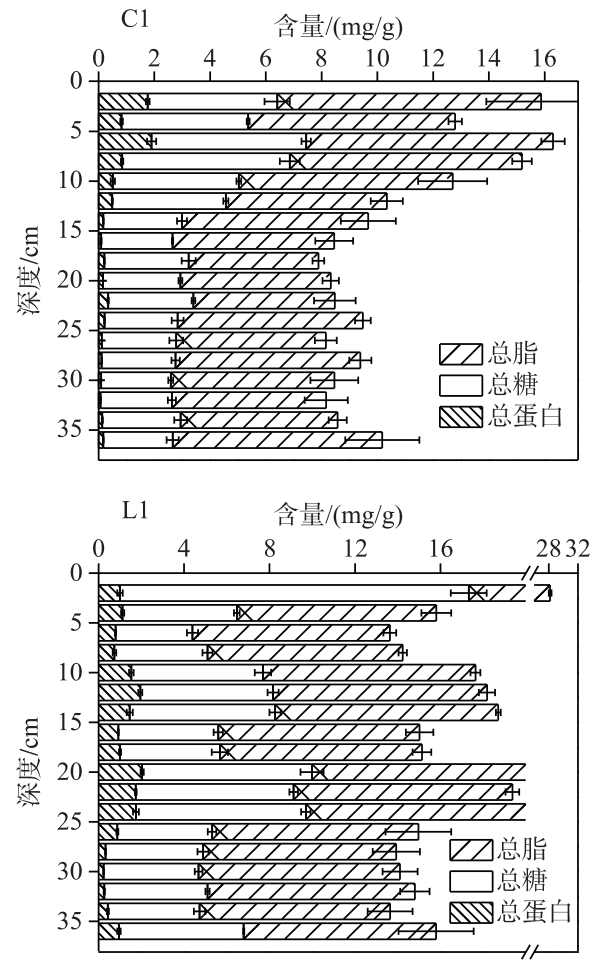
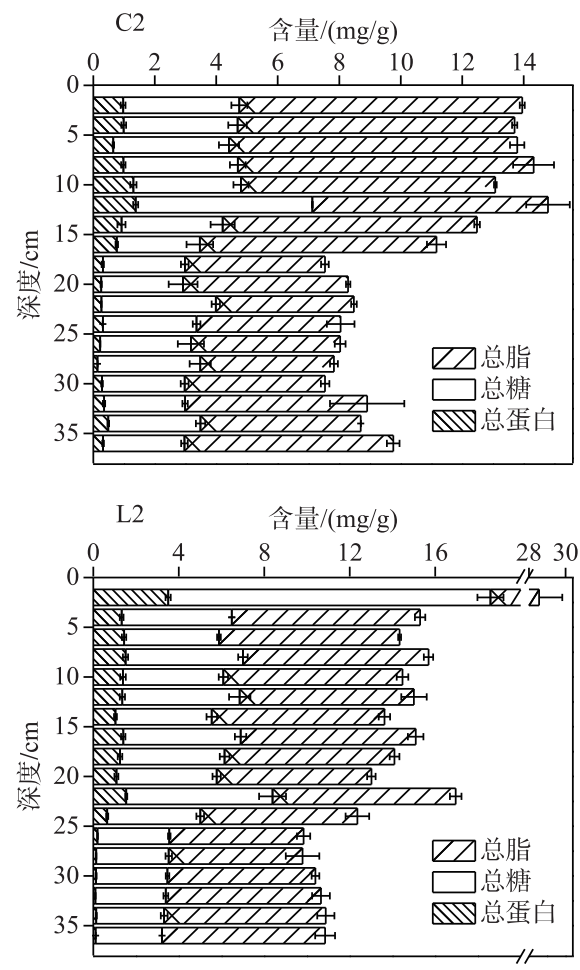

图 6 沉积物中生物易降解有机质的垂向变化

Fig.6 Vertical changes of biodegradable compounds in the sediment profiles

源性混合输人的特征.

4) 藻型湖区沉积物中生物易降解有机质的组成和分布存在明显的空间异质性. 组成上以脂类为主, 其 次是糖类, 蛋白质含量最低; 空间上, 湖滨带沉积物中生物易降解有机质含量显著高于开敞湖区.

\section{4 参考文献}

[ 1 ] Tao Y, Yu J, Lei G et al. Indirect influence of eutrophication on air-water exchange fluxes, sinking fluxes, and occurrence of polycyclic aromatic hydrocarbons. Water Research, 2017, 122: 512-525.

[ 2 ] Xu FL, Yang C, He W et al. Bias and association of sediment organic matter source apportionment indicators: A case study in a eutrophic Lake Chaohu, China. Science of the Total Environment, 2017, 581: 874-884.

[ 3 ] Matisoff G, Watson SB, Guo J et al. Sediment and nutrient distribution and resuspension in Lake Winnipeg. Science of the Total Environment, 2017, 575: 173-186.

[ 4 ] Tammeorg O, Möls T, Laugaste R et al. Wind-induced sediment resuspension as a potential factor sustaining eutrophication in large and shallow Lake Peipsi. Aquatic Sciences, 2013, 75(4) : 559-570.

[ 5 ] Spooner DR, Maher W. Benthic sediment composition and nutrient cycling in an intermittently closed and open lake lagoon. Journal of Marine Systems, 2009, 75(1) : 33-45.

[ 6 ] He YZ, Ke F, Feng MH et al. Characteristics and distribution of biodegradable compounds of surface sediments in Lake Chaohu. J Lake Sci, 2016, 28(1) : 40-49. DOI: 10.18307/2016.0105. [何延召, 柯凡, 冯慕华等. 巢湖表层沉积物 中生物易降解物质成分特征与分布规律. 湖泊科学, 2016, 28(1): 40-49.]

[ 7 ] Wang YR, Chen XC, Chen BF et al. The release of pollutants in sediment-water interface after algal-debris accumulated in sediments. Acta Scientiae Circumstantiae, 2018, 38(1) : 142-153. [王亚荵, 陈向超, 陈丙法等. 藻屑堆积对沉积物水界面污染物的释放效应. 环境科学学报, 2018, 38(1) : 142-153.] 
[ 8 ] Brown MR. The amino-acid and sugar composition of 16 species of microalgae used in mariculture. Journal of Experimental Marine Biology \& Ecology, 1991, 145( 1) : 79-99.

[ 9 ] Brown MR, Jeffrey SW, Volkman JK et al. Nutritional properties of microalgae for mariculture. Aquaculture, 1997, 151 $(1-4): 315-331$.

[10] Brune DE, Lundquist TJ, Benemann JR et al. Microalgal biomass for greenhouse gas reductions : potential for replacement of fossil fuels and animal feeds. Journal of Environmental Engineering, 2009, 135(11) : 1136-1144.

[11] Gatenby CM, Orcutt DM, Kreeger DA et al. Biochemical composition of three algal species proposed as food for captive freshwater mussels. Journal of Applied Phycology, 2003, 15(1) : 1-11.

[12] Joseph MM, Kumar CSR, Kumar TRG et al. Biogeochemistry of surficial sediments in the intertidal systems of a tropical environment. Chemistry \& Ecology, 2008, 24(4) : 247-258.

[13] Zhang XJ, Zhang Y, Wang H et al. Emergent drinking water treatment for taste and odor control in Wuxi City water pollution incident. Water \& Wastewater Engineering, 2007, 33(9): 7-12. [张晓健, 张悦, 王欢等. 无锡自来水事件的城市 供水应急除臭处理技术. 给水排水, 2007, 33(9): 7-12.]

[14] Fan CX. Progress and prospect in formation of black bloom in Lake Taihu: A review. J Lake Sci, 2015, 27(4) : 553-566. DOI : 10.18307/2015.0401. [范成新. 太湖湖泛形成研究进展与展望. 湖泊科学, 2015, 27(4) : 553-566.]

[15] Shen QS, Fan CX. Identification of black suspended particles in the algae-induced black bloom water column. J Lake Sci, 2015, 27 (4) : 591-598. DOI: 10.18307/2015.0405. [申秋实, 范成新. 藻源性湖泛水体显黑颗粒的元素形态分析 与鉴定. 湖泊科学, 2015, 27(4): 591-598.]

[16] Shen Q, Fan C, Liu C et al. The limiting factor to the outbreak of lake black bloom: Roles of ferrous iron and sulfide ions. Clean Soil Air Water, 2018, 46(9): 1-7.

[17] Duan H, Ma R, Loiselle SA et al. Optical characterization of black water blooms in eutrophic waters. Science of the Total Environment, 2014, 482(3): 174-183.

[18] He Y, Song N, Jiang HL. Effects of dissolved organic matter leaching from macrophyte litter on black water events in shallow lakes. Environmental Science \& Pollution Research, 2018, 25(10) : 1-12.

[19] Zhou Y, Jeppesen E, Zhang Y et al. Chromophoric dissolved organic matter of black waters in a highly eutrophic Chinese lake: Freshly produced from algal scums? Journal of Hazardous Materials, 2015, 299(6) : 222-230.

[20] Qi C, Wang GX, Wu XT et al. Deposition characteristics of suspended solids and the response of dissolved nutrients in spring in the western lakeside of Taihu Lake. Environmental Science, 2017, 38(1): 95-103. [祁闯, 王国祥, 吴馨婷等. 太湖湖滨带春季悬浮物沉降特征与水体营养盐响应. 环境科学, 2017, 38(1): 95-103.]

[21] Wu XT, Qi C, Xu XG et al. Simulation of cyanobacteria decay's impacts on nutrients in Water. Acta Scientiae Circumstantiae, 2017, 37 (8) : 2846-2853. [吴馨婷, 祁闯, 许晓光等. 蓝藻腐解对水中营养盐影响的模拟研究. 环境科学学 报, 2017, 37(8): 2846-2853.]

[22] Li J, Zhang Y, Katsev S. Phosphorus recycling in deeply oxygenated sediments in Lake Superior controlled by organic matter mineralization. Limnology and Oceanography, 2018, 63(3) : 1-14.

[23] Meyers PA, Ishiwatari R. Lacustrine organic geochemistry-An overview of indicators of organic matter sources and diagenesis in lake sediments. Organic Geochemistry, 1993, 20(7) : 867-900.

[24] Liu X, Shi C, Xu X et al. Spatial distributions of $\beta$-cyclocitral and $\beta$-ionone in the sediment and overlying water of the west shore of Taihu Lake. Science of the Total Environment, 2017, 579: 430-438.

[25] Department of Ecology and Environment of Jiangsu Province. Bulletin of the 2016 State of the environment in Jiangsu Province, 2016. [ 江苏省环境保护厅. 2016 年江苏省环境状况公报, 2016. ]

[26] Szymczak-Źyła M, Kowalewska G. Chloropigments a in the Gulf of Gdańsk (Baltic Sea) as markers of the state of this environment. Marine Pollution Bulletin, 2007, 55(10) : 512-528.

[27] Heiri O, Lotter AF, Lemcke G. Loss on ignition as a method for estimating organic and carbonate content in sediments : reproducibility and comparability of results. Journal of Paleolimnology, 2001, 25(1) : 101-110.

[28] Venturini N, Pita AL, Brugnoli E et al. Benthic trophic status of sediments in a metropolitan area (Rio de la Plata estuary): Linkages with natural and human pressures. Estuarine Coastal \& Shelf Science, 2012, 112(3) : 139-152.

[29] Pusceddu A, Dell'Anno A, Fabiano M et al. Quantity and bioavailability of sediment organic matter as signatures of benthic trophic status. Marine Ecology Progress, 2009, 375(12) : 41-52. 
[30] Ding S, Chen M, Gong M et al. Internal phosphorus loading from sediments causes seasonal nitrogen limitation for harmful algal blooms. Science of the Total Environment, 2018, 625: 872-884.

[31] Liu GF, Zhong JC, He J et al. Effects of black spots of dead-cyanobacterial mats on Fe-S-P cycling in sediments of Zhushan Bay, Lake Taihu. Environmental Science, 2009, 30(9): 2520-2526. [刘国锋, 钟继承, 何俊等. 太湖竺山湾藻华 黑水团区沉积物中 Fe、S、P 的含量及其形态变化. 环境科学, 2009, 30(9) : 2520-2526. ]

[32] Holmer M, Storkholm P. Sulphate reduction and sulphur cycling in lake sediments: a review. Freshwater Biology, 2001, 46(4): 431-451.

[33] Han C, Ding S, Yao L et al. Dynamics of phosphorus-iron-sulfur at the sediment-water interface influenced by algae blooms decomposition. Journal of Hazardous Materials, 2015, 300: 329-337.

[34] Yu D, Xie P, Zeng C et al. In situ enclosure experiments on the occurrence, development and decline of black bloom and the dynamics of its associated taste and odor compounds. Ecological Engineering, 2016, 87: 246-253.

[35] Waters MN, Schelske CL, Kenney WF et al. The use of sedimentary algal pigments to infer historic algal communities in Lake Apopka, Florida. Journal of Paleolimnology, 2005, 33(1) : 53-71.

[36] Krishnamurthy RV, Bhattacharya SK, Kusumgar S. Palaeoclimatic changes deduced from ${ }^{13} \mathrm{C} /{ }^{12} \mathrm{C}$ and $\mathrm{C} / \mathrm{N}$ ratios of Karewa Lake sediments, India. Nature, 1986, 323(6084) : 150-152.

[37] Huang J, Graham N, Templeton MR et al. A comparison of the role of two blue-green algae in THM and HAA formation. Water Research, 2009, 43(12) : 3009-3018.

[38] Li K, Guan BH, Liu ZW. Experiments on decomposition rate and release forms of nitrogen and phosphorus from the decomposing cyanobacterial detritus. J Lake Sci, 2011, 23(6) : 919-925. DOI: 10.18307/2011.0614. [李柯, 关保华, 刘 正文. 蓝藻碎屑分解速率及氮磷释放形态的实验分析. 湖泊科学, 2011, 23(6) : 919-925.] 